\title{
SESSION IX COMPUTERS IN PSYCHOLOGY: TOOL AND TOPIC
}

John M. Carroll, Presider

Contributers to Discussion*

Landauer, T. K.

Anderson, J. R.

Lewis, C. H.

Norman, D. A.

*Not a paper session
Naming and Paired Associate Learning

Learning to Program in LISP

Thinking About Word Processors and Thinking About Mathematics

Beware the Tar Pits and Sirens of Technology 